\title{
ISLAMIC HEGEMONY IN FORMING RELIGIOUS ATTITUDES: STUDY OF MAJORITY AND MINORITY ISLAM IN SOUTHEAST ASIA
}

\author{
Moh Bashori Alwi Almanduri \\ Universitas Islam Negeri (UIN) Syarif Hidayatullah Jakarta, Indonesia, almanduri96@gmail.com

\section{(c) (1) (-)} \\ (C)2021 by the authors. Submitted for possible open access publication under the terms and conditions \\ of the Creative Commons Attribution-ShareAlike 4.0 International License (CC-BY-SA) \\ license (https://creativecommons.org/licenses/by-sa/4.0/) \\ dof DOI: http://dx.doi.org/10.30983/fuaduna.v5i2.5011

\begin{abstract}
This article critically examines why the dualism of the Islamic model occurs in Southeast Asia. This article uses a historical approach with the literature method to identify how is the map of the distribution of majority and minority Islam in Southeast Asia, what causes the dualism of the Islamic model in Southeast Asia, and how the minority model occurs in the minority Islamic countries. The results show that Islamic syncretism in the archipelago is a logical consequence of the complicated process of struggling religious reflection. His entity also received many challenges from local Indigenous. The majority of Islam is largely determined by the success of harmonizing Islam with political, social and cultural conditions. On the other hand, poor harmonization with the rulers, military invasion, and colonialism cause Muslim minorities. Islamic minority models can be classified into three parts: First, Separatists, such as the Moro Philippines Muslim Separatist movement. Second, accommodating Pattani Muslims in Thailand and Singapore. Third, Genocide happened to Rohingya Muslims in Burma and Khmer Muslims in Cambodia. Furthermore, research on each minority model can be carried out further to enrich the treasures of Islamic studies in Southeast Asia.
\end{abstract}

Keywords: Islamic hegemony; Majority; Minority; Religious Attitudes; Southeast Asia.

\begin{abstract}
Abstrak
Artikel ini menelaah secara kritis mengapa terjadi dualisme model Islam di Asia Tenggara. Artikel ini menggunakan pendekatan historis dengan metode kepustakaan akan mengidentifikasi: Bagaimana peta persebaran Islam mayoritas dan minoritas di Asia Tenggara, apa yang menyebabkan dualisme model Islam di Asia Tenggara, dan bagaimana model keminoritasan yang terjadi pada negara-negara Islam minoritas. Hasil penelitian menunjukkan bahwa Sinkretisme Islam di Nusantara merupakan konsekuensi logis dari proses pergulatan refleksi keagamaan yang rumit. Entitasnya pun banyak mendapatkan tantangan dari Indigeneous lokal. Islam mayoritas sangat ditentukan oleh keberhasilan harmonisasi Islam dengan kondisi politik, sosial, dan budaya. Sebaliknya barmonisasi yang kurang baik dengan penguasa, invasi militer, dan kolonialisme menjadi faktor penyebab minoritas Islam. Model-model minoritas Islam dapat diklasifikasikan menjadi tiga bagian: Pertama, Separatis, seperti gerakan Separatis Muslim Moro Philipina. Kedua, Akomodatif, muslim Pattani di Thailand dan Singapura. Ketiga, Genosida, terjadi kepada muslim Robingya di Burma dan Muslim Kbmer di Kamboja. Selanjutnya penelitian terbadap masing-masing model minoritas bisa dilakukan untuk semakin memperkaya khazanah studi Islam di Asia Tenggara.
\end{abstract}

Kata kunci: Hegemoni Islam; Mayoritas; Minoritas; Sikap Keagamaan; Asia Tenggara. 


\section{INTRODUCTION}

Islam is the most dominant religion in Southeast Asia. It is one of the regions with the largest Muslim population globally, with almost $40 \%$ of the total population being Muslims spread over three countries, namely Indonesia, Malaysia, and Brunei Darussalam. Meanwhile, areas with Muslim minority populations are the Philippines, Myanmar, Thailand, and Singapore. ${ }^{1}$

The presence of Islam in Southeast Asia as the majority is not without reason, but it is the result of the struggle for spiritual reflection of the people of this region who incidentally agrees with the universality of Islam as a religion, having previously been fragmented in the HinduBuddhist aristocratic system for centuries. Islam with its egalitarian concept is considered quite representative and coherent with the noble values of the archipelago $^{2}$ resulting in a very comprehensive Islamic objectivity.

The dominance of Islam as a religion in Southeast Asia also did not escape its introduction model, which (in the end) attracted experts to study it in droves. It is often said that the spread of Islam in this region is a good example of a religious revolution. ${ }^{3}$ The case of the emergence of Islam as a religion that dominates the archipelago is actually contradictory to the mission of Christianization in neighboring countries, the Philippines, for example, which is (currently) dominated by Christians, instead having to go through the drama of wars and military invasions that took many victims. The

1 Omar Farouk Bajunid, Islam and Civil Society in Southeast Asia (Singapore: Institut Of Southeast Asian Studies, 2001), 175.

2 Penulis menggunakan kata Nusantara karena dinilai lebih tepat dan representatif dengan merujuk kepada tiga negara mayoritas Islam di Asia Tenggara yaitu Malaysia, Indonesia dan Brunei Darussalam sebagai negara satu rumpun melayu. Lihat Didin Saepudin, Sejarah Peradaban Islam (Jakarta: UIN Jakarta Press, 2007), 192.

3 Azyumardi Azra, "Intelektual Muslim Baru Dan Kajian Islam," Studia Islamika 1, no. 19 (2012) http://journal.uinjkt.ac.id/index.php/studiaislamika/article/view/373/769. spread of Islam in the archipelago is spread peacefully (penetration pacifique). ${ }^{4}$

However, based on the peaceful spread of Islam, there is a logical consequence that Islam in Southeast Asia has a distinctive character and character that is slightly different or even very different from Islam in its place of origin (the Middle East): that Islam in Southeast Asia is more lenient, docile, accommodating, and tolerance for local culture. The complexity of Islam in Southeast Asia has also made Islamic studies complicated. It has gone through quite a long debate; even the complexity has continued to this day where Islamic studies carried out on this region, whether carried out by Western scholars or Indigenous scholars, have not yet produced an explicit historical, theoretical paradigm. To be used as a guide, instead of being explicit, the theoretical paradigm built by the experts (Western scholars) tends to emphasize the style of Islam in Southeast Asia which is said to be identical to syncretism, for example the views of the orientalists who label Islam in Southeast Asia with Peripheral Islam (peripheral Islam). They judge that Islam in this region is no longer pure like Islam in the Middle East. ${ }^{5}$ Islam is far from the original form as it developed in its place of origin, so it can be said that Islam in Southeast Asia "is not the real Islam". It seems that this justification creates a bias based on the failure of Arabization in the Southeast Asian region as in other regions, for example in North Africa, Central and South Asia, where the spread of Islam was carried out by conquest or "futub".

Furthermore, the development of Islam is actually less slick in the Indochina peninsula and the Philippines, in contrast to the case with its neighbors, the development of Islam in the region is actually under pressure from Buddhist

4 Thomas W Arnold, The Phreaching Of Islam, 361 dalam Azyumardi Azra, Renaisans Islam Asia Tenggara (Bandung: PT Remaja Rosdakarya, 1999), 4. ${ }^{5}$ Azra, 5. 
orthodoxy. Rohingya Muslims in Burma ${ }^{6}$ and Pattani Muslims in Southern Thailand for example, as well as Moro Muslims in Mindanao who had to be pressed by the Christian domination of the Spanish colonial heritage in the Philippines. ${ }^{7}$ In contrast to the Muslims in the Archipelago, the Muslim minority in the region must struggle to get legal standing from the local authorities so that they do not continue to receive intervention and discrimination from the majority in the region. ${ }^{8}$

This research is qualitative research with a historical approach. The author tries to describe the state of Islam within the scope of the Archipelago in the past. It starts from the spread, harmonization, opportunities, and challenges in each region. Then the author will analyze, evaluate and test initial hypotheses related to the causes, effects, and developments of events that might help synergize Islamic historiographical discourse with the dynamics of Islam as the majority and minority in the Archipelago Archipelago, then present it in a descriptive-analytical form within the context of a modern state. which has been formed today in the Southeast Asia region. ${ }^{\text {? }}$

And to prevent the generalization of perspectives, the authors limit the majority of Islamic studies in Indonesia, Malaysia, and Brunei Darussalam. As for Muslim minorities in Thailand, Singapore, the Philippines, Burma, and Cambodia. In addition, the religious attitude that the author refers to in this paper is not in personal

${ }^{6}$ Moshe Yegar, The Muslims Of Burma: A Study Of A Minority Group, dalam Syed Serajul Islam, The Politics Of Islamic Identity In Southeast Asia (Kuala Lumpur: Thomson, 2005), 25.

7 J F Warren, "The Sulu Zone 1768-1878: The Dynamics Of External Trade, Slavery, and Ethnicity," in Transformation of a Southeast Asian Maritime State (Singapore: Singapore University Press, 1981), 23.

8 M Dahlan, "Dinamika Perkembangan Islam Di Asia Tenggara Perspektif Histori," Jurnal Adabiah XIII, no. 1 (2013) http://journal.uinalauddin.ac.id/index.php/adabiyah/article/view/367.

9 Sukardi, Penelitian Kualitatif-Naturalistik Dalam Pendidikan. (Jakarta:Usaha Keluarga. 2006), 45 substance but in the regional, communal and transnational realms.

The method used is the bibliographic or library method, where the writer searches, collects, analyzes, makes interpretations and generalizes the facts which are the opinions of good Muslim historiography experts and scholars. In addition, the author will reveal various theories found in various primary references of this research such as books, reputable scientific articles in the last 10 years, documents, encyclopedias and others of historical value. Furthermore, in analyzing qualitative data, the author will develop explanations or generalizations that approach the data so as to obtain concrete data and context related to the dynamics of the majority and minority Muslims in Southeast Asia. ${ }^{10}$ Furthermore, the purpose of this study is to find out the map of the distribution of majority and minority Islam in Southeast Asia, the causes of dualism in the Islamic model in Southeast Asia, and how the minority model occurs in minority Islamic countries. systematically and objectively by collecting, analyzing, evaluating, verifying, and synthesizing evidence to establish facts and obtain strong and accurate conclusions. ${ }^{11}$ However, in the author's opinion, it is important to carry out further studies related to each of the existing minority models to enrich the study of Islamic treasures in Southeast Asia.

\section{THE PROCESS OF THE ENTRY OF ISLAM IN SOUTHEAST ASIA: AN OVERVIEW OF THEORY}

Geographically, countries in the Southeast Asian region are divided into two categories. First, Mainland Southeast Asia (ATD) which consists of several countries, namely Cambodia, Laos, Myanmar, Thailand, and Vietnam. Second,

10 W.Lawrence Neuman, Social Research Methods: Qualitative and Quantitative Approaches, ed. 7 (UK: Pearson Education, 2014), 479.

11 Sumadi Suryabrata, Metodologi Penelitian (Jakarta: Raja Grafindo Persada, 1998). 
Maritime Southeast Asia (ATM) which consists of: Brunei, the Philippines, Indonesia, Malaysia, Singapore and Timor Leste. ${ }^{12}$

As mentioned in the introduction to this article, until now the theory regarding the process of Islamization in Southeast Asia to become the majority religion shows a fairly high diversification, ${ }^{13}$ especially in the archipelago (Indonesia, Malaysia, and Brunei Darussalam). The diversity of paradigms is fundamentally influenced by what and how experts view the Islamization process.

Citing the views of Azyumardi Azra In general, theories that explain the process of Islamization in Southeast Asia can be classified into three parts: ${ }^{14}$

\section{Arabic theory ${ }^{15}$}

This theory says that Islam came directly from Arabia, more precisely Hadramaut. This theory was put forward by Crawfurd, Keyzer, Nieman, De Hollander, and Veth. Crawfurd stated that Islam came to Southeast Asia directly from Arabia and not from India, while Keyzer stated that Islam came to Southeast Asia from Egypt because of the similarity between the schools of thought adopted by Muslims in Southeast Asia and those adopted in Egypt, namely Madzahb Syafii. Likewise Nieman and De Hollander who hold to the entry of Islam from Hadramaut on the basis of the similarity of the Shafi'i Madzhab adopted by Hadramaut Muslims with Muslims in Southeast Asia. ${ }^{16}$ The same thing

12 Asep Ahmad Hidayat, Studi Islam Di Asia Tenggara (Bandung: Pustaka Setia, 2013), 11.

13 Ragam teori masuknya Islam di Nusantara


Pukul 20.19 WIB

14 Azra, Renaisans Islam Asia Tenggara, 31.

15 Penulis lebih memilih menggunakan kata "Arab" untuk menunjukkan generalisasi wilayah timur tengah, dibandingkan kata "Mekkah" yang dipakai oleh mayoritas penulis studi islam di Asia Tenggara. Sebab penyebaran islam menurut teori ini dari mesir dan hadramaut, sehingga menurut penulis kata mekkah tidak merepresentasikan keduanya. Lihat Moeflich Hasbullah, Sejarah Sosial Intelektual Islam Di Indonesia (Bandung: CV Pustaka Setia, 2012), 4.

16 Teori yang menyatakan bahwa Islam Nusantara berasal dari Arab diantaranya juga dikemukakan oleh was also stated by Hamka in the seminar "History of the Entry of Islam in Southeast Asia" in 1962, he was of the view that Islam entered the archipelago directly from Arabia, not through India, and not in the 11th century but in the first century Hijri. ${ }^{17}$

\section{Gujarati theory}

The first scholar who put forward this theory was Pijnapel in 1872 from the University of Leiden, the Netherlands. He concluded that the Arabs of the Shafi'i school in the Gujarat and Malabar regions had spread Islam to the archipelago as stated in the travel notes of Marcopolo, Ibn Battuta, and Sulaiman. He confirmed his theory by stating that through trade it is possible to transfer relations between these two regions.

G. W. J. Drewes also stated a similar theory; according to him, there are similarities between the two schools of thought. In addition, Snouck Hurgronje argues that India is a haven for Muslims before going to the Archipelago, after they form a strong community, then do Islamization to the Archipelago. Moquette further explained the similarities between Malik Ibrahim's tombstone and the tombstones circulating in Gujarat. However, this opinion seems to be refuted by historical facts which say that Islam did not develop in Gujarat when the first King Samudera Pasai died (698 H / 1297 AD). ${ }^{18}$

\section{Bangladesh Theory}

This theory was popularized by Fatimi, who stated that Islam came from Bengali (present-day Bangladesh). He quoted the opinion

Naguib Al Attas, menurutnya kajian Islam pada masa-masa awal menggunakan literatur Arab, bahkan kajian awal juga menyatakan bahwa Islam bersumber dari Arab. Tokoh sejarawan lainnya yang bermazhab Arab terutama Hadramaut dan Mesir adalah Crawfurd, Keyzer, Niemann, de Hollander, dan Veth. Baca Nur Syam, Islam Pesisir (Yogyakarta: LKiS, 2005), 61; baca juga Azyumardi Azra, Jaringan Ulama Timur Tengah Dan Kepulauan Nusantara Abad XVII Dan XVIII (Bandung: Melacak Akar-akar Pembaruan Pemikiran Islam di Indonesia, 1998), 31.

17 Rusydi Hamka, Hamka Dalam Dakwah Dan

Pembaruan Islam (Panji Masyarakat, 1988), 26.

18 Syam, Islam Pesisir, 59-60. 
of Tome Pures, who said that the majority of nobles in Pasai were Bengalis, and Islam first emerged from the east coast of the Malayan peninsula, not from the West (Malacca). However, this theory is opposed by Snouck because the dominant school in Bengal is the Hanafi School, not the Syafi'i school as in the archipelago.

In addition to some of the theories above, there is also a theory that says that Islam came from Persia, because of the similarities between the Shia Madhhab and the existence of the Shia in the archipelago. ${ }^{19}$ Zahir's various theories indicate that what was formulated by the experts was not final, because the theoretical paradigm they built was only based on existing historical sources without integrating it with the pattern of Islamic development in the archipelago so that it eventually became the majority religion, even breaking pre-Islamic pre-Islamic culture, traditions, and religions.

However, regardless of the interpretation of the experts on when Islam came to Indonesia, the fact is that Islam entered Indonesia through Muslim scholars and traders who have diaspora in various parts of the world since the XI century, and in the XIII century Islam has incarnated as the dominant religion in various fields. archipelago archipelago. The coast of Sumatra and the Malay peninsula became the base areas for the spread of Islam at that time such as Pasai, Aceh, Perlak, Aru, Barus and others. ${ }^{20}$ Furthermore, at the beginning of the XIV century, Samudera Pasai had become the first Islamic empire to strengthen the position of Islam in the archipelago affirmatively, as many tombs of the kings of Pasai were found. Simply put, this condition zahir indicates that Islam has penetrated into the political realm of the archipelago at that time with the acceptance of Islam by the nobles in the royal environment; even in subsequent

19 Musyrifah Sunanto, Sejarah Peradaban Islam Indonesia (Jakarta: Raja Grafindo Persada, 2005), 9.

${ }^{20}$ Islam, The Politics Of Islamic Identity In Southeast Asia, 18. developments, cultural acculturation between Islam and local wisdom became a trend of kings or nobles who married the ulama. Muslim. For example, in 1414 the Hindu king Parameswara married the daughter of the Pasai. ${ }^{21}$

\section{ISLAMIC DUALISM MAJORITY AND MINORITY: DESCRIPTIVE EXPLANATION}

Indonesia is a country with a Muslim majority population. The total Muslim population in Indonesia reaches 236.53 million or an estimated $86.88 \%$ of the total population of Indonesia. ${ }^{22}$ As mentioned in the explanation of the theory above, the hegemony of Islam in Indonesia today is not without reason but a struggle for religious reflection, which is quite complicated. In the context of the Islamic Archipelago, it has succeeded in merging in several aspects of the community's life, ranging from politics, society and culture. The Pasai Kingdom, for example, experienced rapid development during the reign of Al-Malikuz Zahir II in 1326-1348 AD. Al-Malikuz Zahir studied religion. He did many activities to promote religion. Ibn Battuta, an expert on Muslim Earth, once visited Pasai in $764 \mathrm{H} / 1345$ AD giving the impression that Pasai at that time was already advanced, both in the field of religion and social order. Pasai as a center for religious activities based on the Shafi'i school and is a major port city for ships from other countries. ${ }^{23}$

In Java, Islam has developed quite rapidly, starting from the decline of the Majapahit kingdom. The distribution is carried out by the guardians who are members of the nine guardians, namely Maulana Malik Ibrahim, Sunan Ampel,

21 A C Milner, "Islam Abd Malaya Kingship," The Journal of the Royal Asiatic Society of Great Britain and Ireland, no. 1 (1981) https://www.jstor.org/stable/25211179.

22 Persentase Pemeluk Agama/Kepercayaan di Indonesia (Juni 2021), https://databoks. katadata.co.id/datapublish/2021/09/30

23 Ahmad Ibrahim, Readings on Islam in Southeast Asia (Singapore: Institute of Southeast Asian Studies, 1985), 25. 
Sunan Bonang, Sunan Giri, Sunan Drajat, Sunan Kalijaga, Sunan Kudus, Sunan Muria and Sunan Gunung Jati. The nine guardians preach to the people according to their talents and expertise. In addition to the Islamic kingdom of Samudera Pasai, in Sumatra also stood the Islamic kingdom of Aceh. When the Portuguese beat the kingdom of Malacca during the reign of Mahmud Shah, King Ibrahim, who had the title Sultan Ali Mughayat Syah managed to unite the entire Aceh region in 1507. Meanwhile, there were Islamic kingdoms in Java, namely the Demak kingdom (approximately 1500-1550), the Banten Islamic Kingdom, the Pajang Kingdom (1546-1580), and the Cirebon Kingdom. In Kalimantan, Islamic kingdoms also grew, such as the Islamic kingdom of Banjar, the Islamic Kingdom of Sukadana, and the Islamic Kingdom of Brunei. Furthermore, the Islamic Kingdom in Sulawesi was the Bugis Islamic Kingdom (Bone), the Islamic Kingdom in Gowa-Tallo. The Islamic kingdoms in Maluku and Nusa Tenggara are the Kingdom of Ternate, Tidore and the Islamic Kingdom of Nusa Tenggara.

Malaysia is one of the countries with a majority Muslim population in Southeast Asia with a Muslim population of $61.3 \%$ or about 19.5 million of the total population in Malaysia. And as much as $58 \%$ of the population in Malaysia is indigenous, all of whom are Muslims. ${ }^{24}$ Islam entered Malaysia through trade routes, because the Malacca strait is an ancient trade route that has connected various civilizations in all corners of the world. Traders and merchants from India, Arabia and China have been back and forth doing trade, the Strait of Malacca became a stopover for merchants before continuing their voyage. For this reason, Malaysia is dubbed as a country that brings together various civilizations, beliefs and religions (Across-Roads Of Religion) ${ }^{25}$ Islam first

24 Nakamura Mitsuo, Islam and Civil Society in Southeast Asia (Singapore: Institut of Southeast Asian Studies, 2001), 77.

25 Kenneth Perry, Southeast Asia: Cross-Roads of Religion (Chicago: University of Chicago Press, 1949), 30. came to Malaysia through Arab merchants in the span of $675 \mathrm{H} / 1276 \mathrm{AD}$, the kingdom of Melaka was the first Islamic kingdom in Malaysia led by Sultan Muhammad Syah.

In Brunei, Islam was discovered after the tombstone of a Chinese Muslim was found in the Rangas area, Jalan Tutong, Bandar Seri Begawan. From this tombstone, it is known that the $\mathrm{Pu}$ family is a Chinese Muslim from the Chuan-chou family during the Sung Dynasty (960-1279 AD) ${ }^{26}$ In another note, it was revealed that Islam entered Brunei for the first time in the 13th century, it was marked by the marriage of the Sultan of Brunei Awang A Bataton to one of the princesses from the kingdom of Singapore in $1363 .{ }^{27}$ The Sultanate of Brunei Darussalam was founded in 1402, led by Sultan Muhammad Syah who ruled from 14021408. During his leadership, Islam began to penetrate the joints of the life of the people of Brunei. He also contributed to the success of the Islamization project.

An Islamic Minority, the Philippines is an archipelagic country consisting of 7,109 tropical islands with 29,629.00 Ha. Manila as the capital city of the Philippines. Catholicism is the state that makes up the majority in this country. According to the official census records of the Philippines in 1990, the number of Muslim groups was only $5 \%$ of the total population of the Filipino community, which is about 2.8 million people out of a total population of 65 million people. ${ }^{28}$ Islam entered the Philippines around the 13th century in the southern part of the Philippines, namely on the island of Mindanao and the island of Sulu. Islam developed through

26 Awang Mohammad Jamil Al-Sufti, Tarsilah Brunei: Sejarah Awal Dan Perkambangan Islam (Bandar Seri Begawan: Jabatan Pusat Sejarah, 1991), 87.

27 Mohd Taib Osman, Islamic Civilization in The Malay World (Kuala Lumpur: Dewan Bahasa dan Pustaka, 1997), 7.

28 Rina Rehayati, "Minoritas Muslim: Belajar Dari Kasus Minoritas Muslim Di Filipina," Jurnal Ushuluddin XVII, no. 2 (2011) http://ejournal.uinsuska.ac.id/index.php/ushuludin/article/view/694. 
trade routes spread by Arabs as Masya'ika, Mukhdumin, and Auliya.

Islam is the second largest religious community in the Philippines, the Islamic groups are spread in Maguindanaou, Maranao, Iranun, and Tausug. The world generally knows this group as Moro Muslims. ${ }^{29}$ The term Moor is taken from the Latin Mauri, which some Ancient Romans often use to refer to the inhabitants of West Algeria and Morocco with the term Moors. This term was first used when the Spaniards came to the Philippines, the Spaniards saw a group of Filipino people who had similarities in religion and customs with the Moors in Spain (Andalusia)..$^{30}$

Basically, Thailand is a country with a majority of Buddhists, this is due to the invasion of Buddhist theology into the country since 1 Millennium ago. ${ }^{31}$ However, its strategic geographical location is between the Australian continent and mainland China, making it easy to reach in maritime trade activities. Typologically, Thailand is dominated by ethnic Thais who are Buddhists, while Islam is embraced by ethnic Malay minorities concentrated in the southern part of Thailand. This community is in a chronic situation, it is an ethnic-religious minority that is separated from the motherland of the Muslim Malay world in Southeast Asia, while at the same time they are considered citizens by the Thai government in Bangkok, even the Malays across the Malaysia border regard them as their brothers and sisters who have not been liberated. ${ }^{32}$ Muslims who are a minority in southern Thailand are concentrated in the provinces of Pattani,

29 Asep Ahmad Hidayat, Studi Kawasan Muslim Minoritas Di Asia Tenggara (Bandung: Pustaka Rahmat, 2014), 99.

30 Ensiklopedi Tematis Dunia Islam Jilid 5, Minoritas Muslim Asia Tenggara (Jakarta: PT. Ikrar Mandiri Abadi, 2002), 476.

31 Upendra Thakur, Some Aspect of Asian Hystory and Culture (New Delhi: Abhinav Publication, 1986), 157.

32 A.Suhrke Noble, Ethnic Conflict and International Relations (New York: Praeger Publisher, 1977), 187.
Narathiwat, Yala and Sulu. ${ }^{33}$ It can be said, they are isolated in the state bureaucracy due to very striking differentiation in terms of religion, language, and culture. The Thai-Buddhist oriented bureaucracy is practically hindered from carrying out its obligations.

As in other Southeast Asian regions, Islam spread to Burma at the end of the XV century; Muslim traders spread Islam from Arabia who were concentrated on the Arakan coast. Islam has indeed been systematically spread in Myanmar, but it is a pity that Islam cannot convert the local population en masse because Islam is not much protected by the rulers at that time. ${ }^{34}$ This was proven when the Buddhist population of Myanmar conquered the Islamic state of Arakan where the Rohingya Muslim population was located. Muslims in Mnyanmar are only about 5\% of the total population of more than 50 million people. ${ }^{35}$ In general, Muslims in Burma can be divided into 4 groups: Indian Muslims (Kala Pathee), Burmese Muslims (Zerbadee), Malay Muslims, Chinese Muslims (Pashu or Panthay). ${ }^{36}$

Furthermore, Islam had entered Singapore in the XV and XVI centuries, when this country was named Tumasik. Most likely, Islam was brought by Muslims from Aceh, Melaka, and Java. And when the British colonialists came to power, there were many Muslims found at that time, so the British established an "Advisory Council for Islamic Religious Affairs", which was tasked with providing input to the colonial government on

33 Bayu Mitra Adhyatma Kusuma, "Masyarakat Muslim Thailand Dan Dampak Psikologis Kebijakan Asimilasi Budaya," Jurnal Hisbah 1, no. 1 (2016) http:/ / journal.uin-

suka.ac.id/dakwah/hisbah/article/view/131-06 .

34 AC. Milner, Islam Abd Malaya Kingship, dalam Ibrahim, Readings on Islam in Southeast Asia, 25.

35 Hussin Mutallib, Islam in Southeast Asia (Singapore: Institute Southeast Asian Studies, 2008), 72.

36 Omar Farouk, Muslim Asia Tenggara dari Sejarah Menuju Kebangkitan Islam, dalam Saiful Muzani, Pembangunan Dan Kebangkitan Islam Di Asia Tenggara (Jakarta: LP3ES, n.d.), 193. 
Islamic issues and customs. ${ }^{37}$ The progressive development of Islam in Singapore cannot be separated from the role of Sheikh Abu Bakar AlAsghaf, a Hadramaut cleric who took part in spreading Islam in 1916, in 1927 he founded Madrasah Al-Junaid. Since independence from the Federation of Malaysia in 1965, the Muslim community in Singapore has gradually been integrated into the mainstream of Singaporean society. Of Singapore's population, $17 \%$ are Muslim, and $15 \%$ are of Malay descent.

In the Middle Ages, the Indochina region was nicknamed "Mandala Yuda", which was ruled by three major kingdoms, namely Annam, Khmer and Champa. Islam entered Indochina through Champa. As expressed by Thomas W Arnold, who said that Islam set foot in Champa in the 11th century. Fatimi's opinion also confirms this in her book Islam Comes To Malaysia who says that Islam has long been in Champa, Although at that time, the religion of the majority of the Champa population was Mahayana Buddhism, this opinion refers to several inscriptions found and Marcopolo's travel records who stopped in Champa said that at that time the people of Champa were idolaters. ${ }^{38}$

\section{MAJORITY ISLAM OPPORTUNITIES AND CHALLENGES: ANALYTICAL DESCRIPTIVE}

The harmonization of Islamic relations with the rulers is one of the important factors in the massive development of Islam in Indonesia. Although basically it is the simplicity and universality that causes Islam to be easily accepted by the people of the Archipelago. ${ }^{39}$ Pires and Simon express this that Islamic teachings contain family values (tribalism). Besides that, the

Tenggara, 91

37 Hidayat, Studi Kawasan Muslim Minoritas Di Asia

38 Fatimi, Islam Comes to Malaysia (Singapore:

Malaysian Sosiological Research Institute, 1963), 53.

39 Cortesao, The Suma Oriental, Simon, The

Progress And Arrest Of Islam, dalam Azra, Renaisans Islam Asia Tenggara, 39. dynamic teachings of Islam are assimilated with the Indigenous people of the Archipelago. This condition gives birth to syncretism ${ }^{40}$ Islam in the Archipelago, which was the Islamic model by most Western Orientalists, was justified as Peripheral Islam. Because the variety of traditions, rituals, and models of Islam in Indonesia holistically will hardly be found in other Islamic areas on this earth. for example, Kejawen Islam in Java, the Indigenous philosophy of Adat Basandi Syarak, Syarak Basandi Kitabullab in Minangkabau, and the concept of the State of Darussalam in Aceh.

Furthermore, Alwi Shihab in his dissertation revealed that the most widely accepted view is that Islam has been accepted peacefully by the Indonesian people through the teachings of the Sufis. When compared with other branches of Islamic discipline, Sufism is generally recognized as the discipline that has the greatest role in the spread of Islam in Indonesia. ${ }^{41}$ Such a difficult Islamic journey in Indonesia later gave birth to Muslim scholars and intellectuals, such as Nuruddin Ar-Raniri, Hamzah Fansuri, Abd Rauf As-Singkili and others. ${ }^{42}$ The scientific tradition was finally manifested in the form of scientific institutions scattered throughout the archipelago such as Dayah in Aceh, Surau in Minangkabau, and Islamic boarding school in Java.

However, amid the optimism of the development of Islam in the archipelago, it is important to know that the arrival of this entity cannot be separated from challenges and friction with the indigenous people of the archipelago time was dominated by Hindus and Buddhists. The penetration Pacifique adage, which experts commonly use to identify the peaceful spread of

${ }^{40}$ A Fachry Ali Bahtiar Effendy, Merambah Jalan Baru Islam: Rekonstruksi Pemikiran Islam Indonesia Masa Orde Baru (Bandung: Mizan, n.d.), 37.

41 Alwi Shihab, The Muhammadiyah Movement and Its Controversy with Christian Mission in Indonesia (Disertasi, Temple University, 1995), 18-19.

42 Hasanu Simon, Misteri Syekh Siti Jenar, Peran Walisongo Dalam Mengislamkan Tanah Jawa (Yogyakarta: Pustaka Belajar, 2007), 14-16. 
Islam in the archipelago, does not mean that the spread of Islam in this region is pure without violence and total war. Call it majapahit, as many Islamic historiography experts have shared the thesis that the entry of Islam into the archipelago in the early 15th century almost coincided with the diminishing influence of Majapahit as a superior Buddhist kingdom. Slamet Mulyana in his work "The collapse of the Hindu-Buddhist kingdom and the emergence of Islamic countries in the archipelago" stated that the establishment of the Demak Bintoro kingdom was the result of a resounding victory from the war between Raden Fattah who had converted to Islam and troops from the Majapahit kingdom who was currently experiencing internal conflict in the war. the struggle for the throne. Majapahit as the center of Buddhism was increasingly cornered by Demak Bintoro (at that time it was still called Glagah Wangi village). The war took place from 14781517 which ended with the disappearance of Majapahit from the map of the archipelago (although the city of Majapahit at that time was not immediately destroyed, but it has lost its influence in the political arena in the archipelago). On the other hand, Demak Bintoro emerged as an Islamic empire with new powers that succeeded in controlling important sectors in Java and bringing the people of the archipelago to a more modern civilization. ${ }^{43}$

In addition, the development of Islam in the archipelago is also inseparable from the role of Chinese traders. As the consensus of experts that Islam in the archipelago is not an authentic Islam like Islam in the Arabian Peninsula. The entity has been hybridized with various cultural variants which have resulted in Hybrid Islam or in Azra Islam Syncretism. Historiography experts who support this theory include Sumanto AlQurtubi who reveals in his work "Arus Cina Islam-Java" that Muslim traders from China

43 Slamet Muljana, Runtubnya Kerajaan Hindu Budha Dan Timbulnya Negara-Negara Islam Di Nusantara (Yogyakarta: LkiS Pelangi Nusantara, 2005), 129. began to enter Indonesia in the 15-16th century and took part in the spread of Islam in this region. Historiography experts who support this theory include Sumanto Al-Qurtubi who reveals in his work "Arus Cina Islam-Java" that Muslim traders from China began to enter Indonesia in the 1516th century and took part in the spread of Islam in this region ${ }^{44}$. Meanwhile, Ceng Ho was called Admiral because of his expertise in leading the shipping of Chinese traders from mainland China to the archipelago. In spreading Islam he is known to be wise and wise, besides that he is also an accomplished diplomat who is able to build relations with several kingdoms and countries in the global world. ${ }^{45}$

After independence, Islam increasingly gained a strategic position in the country with the establishment of the Majelis Ulama Indonesia $(\mathrm{MUI})^{46}$ which regulates religious matters, ranging from fatwas, Islamic da'wah, tasih al-qur'an, to halal certification of products to be distributed so as to ensure the halalness of these products for consumption by Muslims in Indonesia. In addition, the domination of Islam over the state is also manifested in the form of the Ministry of Religion which is quite contributing, so that Muslims are greatly helped to carry out amaliyah worship such as marriage at the Kantor Urusan Agama (KUA), Hajj, the determination of the beginning of Ramadan-early Shawwal (Eid AlFitr), the Badan Amil Zakat Nasional (BAZNAS) and others, which in fact other religions do not have, where they must be independent in regulating their respective religious people. And in terms of education, the state has established more than 50 Perguruan Tinggi Keagamaan Islam

44 Sumanto Al-Qurtubi, Arus Cina Islam-Jawa (Jakarta: Inspeal Ahimsakaraya Press, 2003), 124.

45 Baha Zarkhoviche, Laksamana Ceng Ho Panglima Islam Penakluk Dunia (Yogyakarta: Araska, 2016), 1.

${ }^{46}$ Majelis Ulama Indonesia didirikan pada tahun 1975 atas inisiatif Pemerintah Republik Indonesia dengan tujuan untuk mengontrol ekspresi publik islam dibawah naungan negara dalam hal ini adalah kementrian agama. M B Hooker, Indonesian Islam Social Change Through Contemporary Fatåwå (Honolulu: University of Hawai'i Press, 2003), 60. 
Negeri (PTKIN) spread throughout the archipelago under the management of the Ministry of Religion of the Republic of Indonesia. $^{47}$

In the context of the Malaysian state, it is important to know that the social and political culture in Malaysia is highly integrated with Islamic values and teachings, this is supported by the strategic role of the kingdom as the center of power in Malaysia, this is stated in the Malaysian constitution which is based on Islamic law. ${ }^{48}$ The Islamic movement showed a significant development after Malaysia became independent from British colonialism in 1957 by applying Islamic values and teachings to its population which was immediately supported by the government/kingdom. The progress of the spread of Islam throughout Malaysia (even to the lowest levels of society) is to produce a quality society, so that it becomes a Muslim country in Southeast Asia. ${ }^{49}$

The state tries to apply Islamic values that are syncretic with Malay culture as a form of national identity, for example by implementing the use of the Malay songkok in government circles, one thing that makes local non-Muslims feel forced to use Islamic attributes. Even though the songkok is not an Islamic tradition and teaching because the prophet never did it, it is purely Malay culture integrated with Islam as a substitute for imamah/turban. ${ }^{50}$ The existence of Islam was increasingly established when the Malaysian government began to form integrative

47 Syafiq Hasyim, Education Reform And Modernisation In Indonesia: Crtical Reflection On Role Of Islamic Higher Educational Institutions And Pesantren In The Making Of Progressive Islam, dalam Muslim Reform in Southeast Asia; Perspective From Malaysia, Indonesia, And Singapore (Majelis Ugama Islam Singapura, 2009), 60.

48 Islam, The Politics Of Islamic Identity In Southeast Asia, 115.

49 Abdull Rahman Mahmood Dkk, "Penerimaan Bukan Islam Terhadap Proses Islamisasi Di Malaysia," Jurnal Hadhari, 2009 http://journalarticle.ukm.my/240/1/1.pdf .

50 Mohd Asri Zainul Abidin, Islam in Malaysia: Percepcionts and Facts (Petaling Jaya: Matahari's Book, 2010), 95.
Islamic institutions for the benefit of Islam, such as the Yayasan Dakwah Islamiyah Malaysia $\left(\right.$ YADIM $^{51}$ which aims to harmonize the activities of da'wah agencies so that they go hand in hand with state policy. In addition, the Malaysian state is also increasingly established in carrying out Islamization on all fronts, so that the discourse on the formation of Malaysia as a Muslim country is a necessity. In the early 1970s, an organization called Angkatan Belia Islam Malaysia (ABIM) was established to counter the swift current of secularism education, which was believed to impact culture, intellectuals, administration, and law negatively. Young Malaysians regard Secularism as the biggest challenge to Malaysia's Muslim community, whose dominance is also felt in the country's politics and economy.

The central role of Islam in Malaysia reached its peak when Mahatir Mohammad came to power, the Islamic policies became a springboard for the Islamization of public life, even though it was unmatched by his predecessors in scope and articulation. This new development attracted many ABIM members. They were willing to join in the task of providing intellectual justification for Islamization and initiating or implementing concrete programs, especially in the establishment of new public institutions such as the International Islamic University and the Islamic banking system. Therefore, during his time Islamic universities such as the International Islamic University of Malaysia (1983) and Islamic banks such as Bank Islam Malaysia (1983) start to sporadic. ${ }^{52}$

Brunei Darussalam became independent from British colonialism on December 31, 1983

51 YADIM didirikan oleh Almarhum Tun Haji Abdul Razak bin Hussein, Perdana Menteri Malaysia yang ke-2 pada 25 Januari 1974 / 1 Muharam 1394H. Lihat Yayasan Dakwah Islamiah Malaysia, 40 Tabun YADIM: Menelusuri Empat Dasawarsa Dakwah, (Kuala Lumpur: YADIM, 2015)

52 Diane K.Mauzy R.S. Kline, The Mabatir Administration in Malaysia; Discipline Trough Islam (Paciffic Affairs, 1983), 643. 
and the 29th Sultan Hassanal Bolkiah Mu'izaddin Wadaulah Sultan as its head of state, during his leadership the modern state of Brunei was transformed into an advanced Islamic country both in terms of socio-economic, educational and cultural, the sultan really want to prosper the people by eliminating the cost of education and health. ${ }^{53}$ Not without reason, at a young age, Brunei must spur a start so that it is equal to other countries that were earlier independent. It is also supported by the wealth of natural resources owned by the country with oil and natural gas as priority sectors which account for almost $92 \%$ of the country's revenue. ${ }^{54}$

Islam in Brunei adopts the model of an Islamic state as exemplified by the prophet in Medina. ${ }^{55}$ Brunei is ruled by a Sultan assisted by a Vizier, and a Minister. As in Malaysia and Indonesia, the syncretism of Islamic teachings with local culture is very strong, even Islam is the official religion in Brunei today with a fairly phenomenal philosophy that is, "Melayu Islam Beraja"56 as a fortification of the position of Islam. Islam shows a progressive development that is quite significant and really merges into the identity of the Brunei people. MIB set as the philosophy of the state Brunei Darussalam in 1991 which consisted of 2 principles: First, Islam as a Guiding Principle, and secondly, Islam as a Form of Fortification. This two basic principles was then born the logical consequence of cultivating Islamic values with three concepts, namely: preserving Brunei as a Malay country, preserving Brunei as an Islamic country with Syafi'i (fiqh) and Ahlu Sunnah wal Jama'ah

53 Abd Ghofur, "Islam Dan Politik Di Brunei Darussalam," Jurnal Toleransi: Media Komunikasi Umat Beragama 7, no. 1 (2015) http://ejournal.uinsuska.ac.id/index.php/toleransi/article/view/1421.

${ }^{54}$ Sumber: http://setnas-asean.id/, di akses pada 22 april 2021 pukul 20.05 Asia, 19.

55 Islam, The Politics Of Islamic Identity In Southeast

56 Selanjutnya istilah "Melayu Islam Beraja" akan disingkat menjadi MIB (monotheism), as well as preserving Brunei as a monarchy (Absolute Monarchy). ${ }^{57}$

The stipulation of Melayu Islam Beraja (MIB) as a state ideology is not an exaggeration; the sultan carried it out to make people loyal to their king, implementing Islamic teachings and laws and making them a way of life that is connected with the characteristics and characteristics of the true Malay nation, including making Malay as the main language. Thus, because of the absolute power that is in the hands of the sultan, it is only natural that Brunei becomes the most politically stable country. ${ }^{58}$

Furthermore, the development of Islamic da'wah in Brunei today has also shown an optimistic significance, it cannot be separated from the intervention of the government to bureaucratize Islamic da'wah in the country. All matters relating to Islamic da'wah are regulated by the Islamic Da'wah Center, ${ }^{59}$ This institution regulates and oversees the movement of Islamic da'wah to always be guided by the understanding of Ahlu Sunnah wal Jama'ah. ${ }^{60}$ Pusat Dakwah Islam (PDI) was established by the Brunei government to filter out Islamic notions from outside that are not following the Malay customs and ensure the existence of Islam that is Ahlu Sunnah Wal Jamaah. For example, by conducting training and cadre of da'i as well as uniforming da'i material for da'i before being deployed to the field. The state does seem over-protective in terms of the scale of Islamic da'wah in the country, and raises suspicions if the state is too interfering in the affairs of Islamic da'wah or even at a more severe level intervenes so that it is directly proportional to the will of the

57 Mahmud Saedon Awang Othman. "Perlaksanaan dan Pentadbiran Undang-undang Islam di Negara Brunei Darussalam: Satu Tinjauan", dalam Ghofur, "Islam Dan Politik Di Brunei Darussalam," 53.

${ }^{58}$ https://id.wikipedia.org/wiki/Brunei Darussala m, diakses pada tanggal 22 april 2021, pukul 20.10 WIB

${ }^{59}$ Lebih lanjut istilah "Pusat Dakwah Islam" akan disingkat menjadi PDI

60 Wahyu Ilaihi Dkk, Pengantar Sejarah Dakwah (Jakarta: Prenadamedia Group, 2005), 170. 
government for political interests (politicization of religion). For example, by requiring the da'i to submit material to obey the sultan, but it reinforces the government's commitment to maintaining political, social and cultural stability in the country as well as a form of legal standing for the application of the concept of the Darussalam state (house of safety).

\section{MINORITY ISLAMIC FACTORS:}

\section{A MODEL}

Separatist Islam was present in the Philippines long before the arrival of Catholic Christianity through Spanish colonialism in 1521. The arrival of the Spaniards in the Philippines aimed to build several areas with the concept of Christianization, which then had a significant influence on the lives of the Filipino people directly. ${ }^{61}$

In 1951, several organizations from Muslim countries assisted by establishing several schools and building several mosques in the Southern Philippines region. Another assistance was also provided by the Egyptian government which provided scholarship assistance to Moro residents who wanted to study at several universities in Egypt. Several volunteers from abroad also provided compensation through the teaching-learning process, especially in the Southern Philippines. Besides developing the education and teaching process in Moro, scholars from Muslim countries also participate in teaching Islamic Religious Education in Moro. Along with the development of Islam in Moro, there were several conflicts between Christians who were directly supported by the government aimed at destroying the Islamization process in the Philippines, namely by: (a) Spreading Christianization in several Muslim population areas which were directly supported and received legality from the government. government. (b) Deteriorating the economy, health and education

${ }^{61}$ Rehayati, "Minoritas Muslim: Belajar Dari Kasus Minoritas Muslim Di Filipina," 234. of Moro Muslims. (c) The discrimination by Christians against Muslims in Moro in several government offices. (d) The loss of power for Muslims in Moro, especially in the political sphere. (e) The Christians seized the lands of the Muslim population in Moro.

Accommodatively, in Thailand, the MalayMuslim Community opposed what geerts. later called the "Integration Revolution" that new countries usually faced. ${ }^{62}$ The early history of the Patani kingdom was first known as the Hindu-Buddhist kingdom of Langkasuka. ${ }^{63}$ When exactly the Pattani area converted to Islam, it is not yet known for sure. ${ }^{64}$ However, in 1613, D'eredia estimated that Pattani converted to Islam before Melaka, which is traditionally known as the first "Darussalam" (peaceful place) in the region. ${ }^{65}$ Islam is able to add and strengthen the religious, social, cultural and economic aspects in Patani which was formerly called Langkasuka. ${ }^{66}$ Around the 15th century, the Langkasuka kingdom changed its name to the Malay Islamic kingdom (Pattani) by making the sultanate the system of government and Islam the official religion. In the 16th-17th century, Pattani experienced its peak of success as a trading region, but this also made Patani a target area for other regions, namely the Siamese kingdom of Thailand, which would later make the

62 Clifford Geertz, Old Societies And New States (New York: The Free Press, 1963), 105.

63 Jhon F, Thailand, "Voice of Islam in Southeat Asia; A Contemporary Sourcebook, Institute of Southeast Asian Studies," 2006, 78.

${ }^{64}$ R. Winzeler, The social Organizatition Of Islam Kelantan, dalam William Roff and Kelantan, Religion and Politics in A Malay State (Kuala Lumpur: Oxford University Press, 1974), 260.

65 J. Mills, "Eredia's Description Of Malacca, Meridional India, And Cathay", Journal of The Malayan Branch of The Royal Asiatic Society, Vol VIII no 1, 1930), https://www.jstor.org/stable/41493368

${ }^{66}$ Kerajaan ini merupakan cikal bakal dari kerjaan Pattani yang terletak di pantai timur semenanjung Malaya antara Klantan dan Songkhla, ini berdasarkan catatan China. Welch dan McNeill memiliki pendapat lain, mereka menyatakan bahwa Langkasuka merupakan nama lain dari kesultanan Patani., M. Ladd Thomas, "Political Violence In The Muslim Provinces Of Southen Thailand", ISEAS No. 28,(1975),https://bookshop.iseas.edu.sg/publication/1060 
Siamese conquest of Pattani as well as a new round of marginalization of this ethnicity in the state bureaucracy Modern Thailand.

Definitively the territory of the Islamic kingdom of Pattani was integrated into the modern Thai state in 1902 which was certainly full of protests and rebellions. Pattani in the present context is termed "Masyarakat Melayu" which is almost synonymous with "Rural Community" when used in the context of Southern Thailand. This reflects their economic life and social relations, because urban areas are predominantly Thai-Buddhist bases associated with the state bureaucracy and Chinese merchants. ${ }^{67}$ This seemingly forced integration effort gave birth to the first rebellion in 1903 led by the then king of Pattani Abdul Kadir, by provoking the Thai rulers to act tough, at the same time he asked the British for help, which at that time was paying more attention to the Malay countries. ${ }^{68}$

Finally, rebellion after rebellion occurred in order to demand special autonomy for the Muslim minority area such as in 1945-1957 demanding autonomy in the legal field under the Absolute Monarchy, government integration efforts from 1957-1973, even to the way of violence in 1973-1982 until now. Take the recent attack that killed two monks at the Wat Rattananupab temple, in Su Ngai Padi District, Narathiwat Province. Previously in 2019 there were attacks on schools and hospitals carried out by the Barisan Revolusi Nasional (BRN) rebel group. This attack is a form of protracted conflict carried out by the movement to fight for special autonomy rights for Muslims in the region which the Thai Buddhist government has not granted. This condition is a reaction to the policies of the Buddhist government which requires Muslims to accommodate with unequal rules. For example,

\footnotetext{
${ }^{67}$ Surin Pitsuwan, Islam Di Muangthai, Nasionalisme Melayu Masyarakat Pattani (Jakarta: LP3ES, 1989), 17.

68 Kiernan, "Britain, Siam and Malaya: 18751885"," The Journal Of Modern History, no. 1 (1956) https://www.journals.uchicago.edu/doi/abs/10.1086/2378 48?journalCode $=$ jmh .
}

using Thai as the official national language and replacing Islamic names with names in Thai ${ }^{69}$

The development of Islam in Singapore continues to show a significant increase. Until 2007, Muslims in Singapore accounted for 15\% of the total population (around 650 thousand people, of the 3.5 million population as a whole). Amid the secular life system implemented by the Singapore government, Muslims there must continue to race to improve their quality, in order to be able to compete with the rapid progress of Information Technology and the times.

As a second class society ${ }^{70}$ Muslims in Singapore must continue to make efforts to adapt to the mainstream of this country's society and existing regulations. For example, the regulation on the use of loudspeakers for all mosques in Singapore. The sound of loudspeakers is prohibited at certain times, for example at dawn and other obligatory prayers, the sound of the call to prayer from mosques in Singapore will not be heard by the general public as in Indonesia or Malaysia. Islam in Singapore is regulated by the Majelis Ugama Islam Singapura (MUIS) or the Islamic Religious Council of Singapore, an institution at the level of the Ministry of Religion. MUIS regulates all matters related to the administration and activities of Muslims there. For example, by arranging Islamic da'wah materials for the da'i so as not to insinuate or in a more severe level criticize the government.

Genocide, Rohingya Muslim dilemma began in the 1930s when there was an attack on Muslims in Yangon by non-Muslim Burmese soldiers, more than 200 Muslims were killed at that time. Even the attacks that occur tend to want to wipe out the Muslim race in the Buddhist

69 Konflik Etnik Melayu-Muslim di Thailand Selatan: Penyebab, Proses, dan Dinamika, https://pssat.ugm.ac.id/id/konflik-etnik-melayu-muslim-dithailand-selatan-penyebab-proses-dan-dinamika/

70 Hal itu disebabkan mayoritas penduduk Singapura didominasi oleh etnis China yang beragama Budha dan Konghucu. 
country. The following are some of the factors that led to the oppression of the Muslims in the Rohingya, namely: a) There was an attitude of injustice shown by the Military Junta Government in controlling Burma from 1962 until now. b) Buddhists as the majority in Myanmar carry out anti-Islamic movements. c) Muslims managed to become successful traders in Burma so that social jealousy arose for non-Muslims.

In Cambodia, Islam as a minority religion became an easy target for the communist government under the leadership of the Polpot regime which came to power in 1979, more than two million Cambodians were massacred and 90,000 of them were Muslims. This genocide was an attempt to rid Cambodia of ethnicities other than the Khmer Rouge, in addition to changing the shape of the Cambodian state from democratic to communist. ${ }^{71}$ This resulted in the deaths of 1.5 to 2 million people from 1975-1979, almost a quarter of Cambodia's 1975 population of around 7.8 million. $^{72}$

\section{CONCLUSION}

Based on the description above, it can be concluded that there are three main points in this article. First, the dualism of Islam in Southeast Asia is formed based on the struggle to reflect religious values which is quite challenging. This process occurred for hundreds of years involving Islamic syncretism, war, negotiation, and resistance between nations, thus creating opposing currents between Islam in the Maritime Southeast Asia region which Islam dominated. And the Mainland Southeast Asia region which is dominated by minority Islamic countries.

Second, there is a strong enough connectivity to determine the domination of Islam in an area, namely the strong harmonization

71 Patrick Heuveline, "Analisis Demografis Krisis Kematian: Kasus Kamboja, 1970-1979 Migrasi Paksa Dan Kematian," National Academic Press, 2001, 102-5.

72 Henri, "State Violence in Democratic Kampuchea (1975-1979) and Retribution (1979-2004)" (European Review of History, n.d.), 121-43. of Islam in political, social, and cultural aspects. The reality of Islam which was able to enter into the political spaces of the royal elite in the early days, merged into local indigenous peoples, and blended with social values and norms has maintained its existence to this day. On the other hand, minority Islam is evidence of the failure of Islam to establish relations with geopolitical, social and cultural conditions. Although it is undeniable that military invasion and colonialism are factors supporting the Islamic minority.

Third, in general, Muslim minorities can be categorized into three models. Namely, Separatists, like the Moro Muslim minority in the Philippines who were formerly part of the Sulu Sultanate, continue to carry out movements to liberate Moro Muslims. Accommodative, as is the case in Thailand and Singapore where Muslims are forced to synergize with non-Muslim communities in their countries, even though several regulations are deliberately created to suppress the Islamic movement. Genocide, this happened in Indochina and Burma, an attempt to remove certain races or ethnic groups from a region/country. The Polpot Regime did this in Cambodia and the Buddhist government against the Rohingya Muslims in Burma.

\section{REFERENCES}

Abidin, Mohd Asri Zainul. Islam in Malaysia: Percepcionts and Facts. Petaling Jaya: Matahari's Book, 2010.

Al-Qurtubi, Sumanto. Arus Cina Islam-Jawa. Jakarta: Inspeal Ahimsakaraya Press, 2003.

Al-Sufti, Awang Mohammad Jamil. Tarsilah Brunei: Sejarah Awal Dan Perkambangan Islam. Bandar Seri Begawan: Jabatan Pusat Sejarah, 1991.

Azra, Azyumardi. "Intelektual Muslim Baru Dan Kajian Islam." Studia Islamika 1, no. 19 (2012).

- Jaringan Ulama Timur Tengah Dan Kepulauan Nusantara Abad XVII Dan XVIII. Bandung: Melacak Akar-akar Pembaruan Pemikiran Islam di Indonesia, 1998. 
Renaisans Islam Asia Tenggara. Bandung: PT Remaja Rosdakarya, 1999.

Bahtiar Effendy, Fachry Ali. Merambah Jalan Baru Islam: Rekonstruksi Pemikiran Islam Indonesia Masa Orde Baru. Bandung: Mizan, n.d.

Bajunid, Omar Farouk. Islam and Civil Society in Southeast Asia. Singapore: Institut Of Southeast Asian Studies, 2001.

Dahlan, M. "Dinamika Perkembangan Islam Di Asia Tenggara Perspektif Histori." Jurnal Adabiah XIII, no. 1 (2013).

Didin Saepudin. Sejarah Peradaban Islam. Jakarta: UIN Jakarta Press, 2007.

Ensiklopedi Tematis Dunia Islam Jilid 5, Minoritas Muslim Asia Tenggara. Jakarta: PT. Ikrar Mandiri Abadi, 2002.

Fatimi. Islam Comes to Malaysia. Singapore: Malaysian Sosiological Research Institute, 1963.

Geertz, Clifford. Old Societies And New States. New York: The Free Press, 1963.

Ghofur, Abd. "Islam Dan Politik Di Brunei Darussalam." Jurnal Toleransi: Media Komunikasi Umat Beragama 7, no. 1 (2015).

Hamka, Rusydi. Hamka Dalam Dakwah Dan Pembaruan Islam. Panji Masyarakat, 1988.

Hasbullah, Moeflich. Sejarah Sosial Intelektual Islam Di Indonesia. Bandung: CV Pustaka Setia, 2012.

Henri. "State Violence in Democratic Kampuchea (1975-1979) and Retribution (19792004)." European Review of History, n.d.

Heuveline, Patrick. "Analisis Demografis Krisis Kematian: Kasus Kamboja, 1970-1979 Migrasi Paksa Dan Kematian." National Academic Press, 2001.

Hidayat, Asep Ahmad. Studi Islam Di Asia Tenggara. Bandung: Pustaka Setia, 2013. - Studi Kawasan Muslim Minoritas Di Asia Tenggara. Bandung: Pustaka Rahmat, 2014.

Hooker, M B. Indonesian Islam Social Change Through Contemporary Fatåwå. Honolulu: University of Hawai'i Press, 2003.

Ibrahim, Ahmad. Readings on Islam in Southeast Asia. Singapore: Institute of Southeast Asian Studies, 1985.

Ilaihi, Wahyu dkk. Pengantar Sejarah Dakwah. Jakarta: Prenadamedia Group, 2005.

Islam, Syed Serajul. The Politics Of Islamic Identity In Southeast Asia. Kuala Lumpur: Thomson, 2005.
Kiernan. "Britain, Siam and Malaya: 1875-1885"." The Journal Of Modern History, no. 1 (1956).

Kusuma, Bayu Mitra Adhyatma. "Masyarakat Muslim Thailand Dan Dampak Psikologis Kebijakan Asimilasi Budaya." Jurnal Hisbah 1, no. 1 (2016).

Mahmood, Abdull Rahman dkk. "Penerimaan Bukan Islam Terhadap Proses Islamisasi Di Malaysia." Jurnal Hadhari, 2009.

Milner, A C. "Islam Abd Malaya Kingship." The Journal of the Royal Asiatic Society of Great Britain and Ireland, no. 1 (1981).

Mitsuo, Nakamura. Islam and Civil Society in Southeast Asia. Singapore: Institut of Southeast Asian Studies, 2001.

Muljana, Slamet. Runtubnya Kerajaan Hindu Budba Dan Timbulnya Negara-Negara Islam Di Nusantara. Yogyakarta: LkiS Pelangi Nusantara, 2005.

Muslim Reform in Southeast Asia; Perspective From Malaysia, Indonesia, And Singapore. Majelis Ugama Islam Singapura, 2009.

Mutallib, Hussin. Islam in Southeast Asia. Singapore: Institute Southeast Asian Studies, 2008.

Muzani, Saiful. Pembangunan Dan Kebangkitan Islam Di Asia Tenggara. Jakarta: LP3ES, n.d.

Neuman, W.Lawrence. Social Research Methods: Qualitative and Quantitative Approaches. Ed. 7. UK: Pearson Education, 2014.

Noble, A.Suhrke. Ethnic Conflict and International Relations. New York: Praeger Publisher, 1977.

Osman, Mohd Taib. Islamic Civilization in The Malay World. Kuala Lumpur: Dewan Bahasa dan Pustaka, 1997.

Perry, Kenneth. Southeast Asia: Cross-Roads of Religion. Chicago: University of Chicago Press, 1949.

Pitsuwan, Surin. Islam Di Muangthai, Nasionalisme Melayu Masyarakat Pattani. Jakarta: LP3ES, 1989.

R.S. Kline, Diane K.Mauzy. The Mahatir Administration in Malaysia; Discipline Trough Islam. Paciffic Affairs, 1983.

Rehayati, Rina. "Minoritas Muslim: Belajar Dari Kasus Minoritas Muslim Di Filipina." Jurnal Ushuluddin XVII, no. 2 (2011).

Roff, William, and Kelantan. Religion and Politics in A Malay State. Kuala Lumpur: Oxford University Press, 1974. 
Shihab, Alwi. The Mubammadiyah Movement and Its Controversy with Christian Mission in Indonesia. Disertasi, Temple University, 1995.

Simon, Hasanu. Misteri Syekh Siti Jenar, Peran Walisongo Dalam Mengislamkan Tanah Jawa. Yogyakarta: Pustaka Belajar, 2007.

Sunanto, Musyrifah. Sejarah Peradaban Islam Indonesia. Jakarta: Raja Grafindo Persada, 2005.

Suryabrata, Sumadi. Metodologi Penelitian. Jakarta: Raja Grafindo Persada, 1998.

Syam, Nur. Islam Pesisir. Yogyakarta: LKiS, 2005.

Thakur, Upendra. Some Aspect of Asian Hystory and Culture. New Delhi: Abhinav Publication, 1986.

"Voice of Islam in Southeat Asia; A Contemporary Sourcebook, Institute of Southeast Asian Studies," 2006.

Warren, J F. “The Sulu Zone 1768-1878: The Dynamics Of External Trade, Slavery, and Ethnicity." In Transformation of a Southeast Asian Maritime State. Singapore: Singapore University Press, 1981.

Zarkhoviche, Baha. Laksamana Ceng Ho Panglima Islam Penakluk Dunia. Yogyakarta: Araska, 2016.

\section{Website}

https://id.wikipedia.org/wiki/Brunei Darussala m, diakses pada tanggal 22 april 2021, pukul 20.10 WIB

Konflik Etnik Melayu-Muslim di Thailand Selatan: Penyebab, Proses, dan Dinamika, https://pssat.ugm.ac.id/id/konflik-etnikmelayu-muslim-di-thailand-selatanpenyebab-proses-dan-dinamika/

Persentase Pemeluk Agama/Kepercayaan di Indonesia (Juni 2021), https://databoks.katadata.co.id/datapub lish/2021/09/30/

Ragam teori masuknya Islam di Nusantara https://databoks.katadata.co.id, di akses pada 20 april 2021 Pukul 20.19 WIB

Sumber: http://setnas-asean.id/, di akses pada 22 april 2021 pukul 20.05 